\title{
C FROM ETHICAL CODES TO ETHICAL AUDITING: AN ETHICAL INFRASTRUCTURE FOR SOCIAL RESPONSIBILITY COMMUNICATION
}

\author{
De los códigos a las auditorías éticas: una \\ infraestructura ética para la comunicación de la \\ responsabilidad social
}

\author{
Domingo García-Marzá
}

Nota: Este artículo se puede leer en español en:

http://www.elprofesionaldelainformacion.com/contenidos/2017/mar/13_esp.pdf

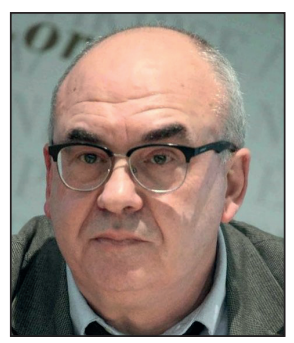

Domingo García-Marzá is a professor of Business Ethics at the Universitat Jaume I in Castellón, Spain. Doctor of Philosophy from the University of Valencia, he has expanded studies of Politics in Frankfurt (Germany) and Economy and Business in St. Gallen (Switzerland) and Notre Dame (United States). He has been Vice Chancellor of Communication, as well as director of the Department of Philosophy and Sociology and, currently, is Commissioner for the Development of University Social Responsibility. He has published his works with prestigious publishers and in national and international journals. His lines of research include: business ethics, applied ethics, deliberative democracy, civil society, as well as ethics and compliance systems. Coordinator of the Interuniversity Master of Ethics and Democracy at Universitat Jaume I, he is co-director of the interuniversity doctorate of excellence of the same name. The results of these investigations have been applied in numerous companies and administrations. Professor García-Marza is a member of several ethics and social responsibility committees. http://orcid.org/0000-0002-9605-1771

Universitat Jaume I, Departamento de Filosofía y Sociología, Facultad de Ciencias Humanas y Sociales Av. Sos Baynat, s/n. 12071 Castellón de la Plana, Spain garmar@uji.es

\begin{abstract}
Organizations' communication and social responsibility have been conceived and used as two completely separate areas, whose relationship is merely instrumental. This has led to a current lack of trust in the mechanisms and procedures of corporate social responsibility information. This article proposes an ethics of communication that defines how to ethically manage corporate social responsibility communication which is capable of specifying the relationships that link ethics, communication, and responsibility. The objective is to present the basic traits of new codes of ethics generation that include both compliance measures and their external verification by ethical auditing. The proposal is important because it establishes an ethical infrastructure from which to recover trust in corporate social responsibility communication. The employed methodology is reconstruction, based on Habermas' Theory of Communicative Action, and also transparency and participation claims that result from discourse ethics.
\end{abstract}

\section{Keywords}

Corporate social responsibility; Ethics; Theory of communicative action; Trust; Critical hermeneutics; Responsible communication; Ethical codes; Ethics committee; Ethics hotline; Compliance; Ethical auditing.

\section{Resumen}

La comunicación y la responsabilidad social de las organizaciones se han concebido y utilizado como dos ámbitos separados, cuya relación sólo es instrumental. El resultado ha sido la actual desconfianza hacia los mecanismos y procedimientos de información de la responsabilidad social. Este artículo propone apoyarse en una ética de la comunicación para, desde ahí, definir las bases para una gestión ética de la comunicación de la responsabilidad social capaz de explicitar la relación entre ética, comunicación y responsabilidad. El objetivo es exponer los rasgos básicos de una nueva generación de códigos de ética que incluyan tanto las medidas de su cumplimiento como su verificación externa a través de una auditoría ética. La importancia de esta propuesta deriva de la necesidad de establecer una infraestructura ética desde la que recuperar la confianza en la comunicación de la responsabilidad social. La metodología utilizada es de corte reconstructivo y se basa en la teoría de la acción comunicativa de Habermas y en las pretensiones de transparencia y participación derivadas de la ética discursiva. 


\section{Palabras clave}

Responsabilidad social corporativa; Ética; Teoría de la acción comunicativa; Confianza; Hermenéutica crítica; Comunicación responsable; Códigos éticos; Comité de ética; Línea ética; Sistemas de ética y cumplimiento; Auditorías éticas.

García-Marzá, Domingo (2017). "From ethical codes to ethical auditing: An ethical infrastructure for social responsibility communication". El profesional de la información, v. 26, n. 2, pp. 268-276.

https://doi.org/10.3145/epi.2017.mar.13

\section{Introduction}

Organizations' communication and social responsibility have been considered and discussed as two separate areas, knowledge and action, whose relationship is merely optional and instrumental. This separation can be observed in the origination of the credibility crisis that is presently associated with mechanisms of corporate social responsibility communication. For this reason, it is necessary to update the way in which these mechanisms are considered and used so that their credibility can be recovered and trust regenerated. This article represents a search, within an ethics of communication, to reveal the basis on which an ethical infrastructure for all types of organizations can be designed to sustain trust in the information that is offered. To this end, the principle of responsibility is formulated as the integration of transparency and participation, and the basic traits of a new generation of ethical codes are presented. These traits include compliance measures, ethical and social responsibility committees, and ethical hotlines. The basic contribution of this proposal is the concept of communication as the basic core of corporate social responsibility, not as a separate or independent element.

The proposal's novelty is the idea that the different elements that make up this ethical infrastructure should be integrated into a system and that compliance with this system requires that ethical auditing be performed to verify the adopted ethical commitment.

\section{Corporate social responsibility: between the ethics of communication and the communication of ethics}

Social responsibility has been incorporated into the language used by corporations (CSR); therefore, social responsibility has been incorporated into the language of public administration (ASR), universities (USR), and generally any type of public or private organization (OSR). However, this incorporation has not created the credibility and trust expected of such a commitment because of the impacts that it has generated and the integration of social, economic, and environmental benefits. In fact, there is currently an argument that proposes its abandonment, showing not only the skepticism but also the direct rejection of the idea of social responsibility and its possible management (MorenoIzquierdo, 2014).

The reasons that support this criticism are not lacking. First, there is the irrefutable fact that corporate social responsibility has not fulfilled expectations. Spain is the country with the most certifications and signed pacts, yet these have proven to have little use in containing the consequences of economic crisis, fraud, and corruption.

In addition to the superficial, merely cosmetic nature of corporate social responsibility, it has also been used to conceal bad organizational practices. Amazing ethical codes and excellent reports of responsibility are currently the new sheep's clothing that disguises injustice and exploitation.

Lastly, many scholars think that discussing voluntaryand self- regulation is simply an excuse for blocking steps towards necessary legal regulation. Only external co-action can guarantee an organization's proper functioning (Laufer, 2003; Klein, 2011).

The misapplication of social responsibility has caused the concept to lose its ability to generate trust and must be reformulated

The result includes a concept of social responsibility that appears to have lost its ability to generate trust in corporations and in organizations in general. We are no longer addressing a key element of corporations' reputations that can anchor an organization's credibility in the sphere of public opinion (Aceituno-Aceituno et al., 2013; García-Marzá, 2014). The root of this criticism can be found in a strategic understanding of CSR as image improvement, a cost savings strategy, or a competitive factor, which is the way that corporations and organizations have understood and used the concept. When CSR is no longer of interest, it is forgotten. It is therefore logical that mistrust would be directed principally at the communication mechanisms that are used by corporations and what the corporation says regarding what it is and what it does. Any recovery of the concept and its objectives must be preceded by a recovery of the trust in this communication (Rademacher; Köhler, 2012). For this reason, we argue that a communication of ethics requires and presupposes an ethics of communication.

On closer examination, the criticism that is presented is not directed at the concept of social responsibility itself but rather at its merely instrumental use and manipulation for cosmetic purposes and image whitewashing. Therefore, the question is not when and how to abandon the concept of CSR and look for substitutes, rather, the question is how to clearly and convincingly differentiate between an ethical use and a strategic use of social responsibility and its communication. The consideration of communication as something internal and essential to social responsibility, not as an ex- 
ternal and circumstantial element, allows us to make this differentiation. Thus, an organization is not responsible and then communicates this, but rather its responsibility exists in communicating what it does. This is the central idea of the proposal that we advance here.

On one hand, although in common language we relate responsibility to cause and even to guilt, the root of the concept can be found in the idea of responding and in the demand to provide an explanation to others regarding what we do and should stop doing. That is, this demand is derived from the need to adjust our behavior to what is expected of us when we establish any type of relationship (López-Aranguren, 1979). This need to adjust behavior also occurs with organizations that depend on their ability to respond to society's legitimate expectations to maintain and strengthen their social credibility. Part of these expectations have a moral nature and refer to the recognition and consideration of others as people of equal dignity who deserve acknowledgement and respect. Ethics explains and justifies, and applied ethics puts these expectations and moral assumptions into practice (Cortina; García-Marzá, 2003).

\section{An organization responsibility exists in communicating what it does}

Trust in people and organizations is based on this ability to adjust and, therefore, justifies our decisions and behaviors to meet other people's expectations. This situation is the case when, for example, corporations have behaved well or poorly, universities are viewed as just or unjust, and administrations are seen as honest or corrupt. The credibility and trust that people and organizations earn are supported by these perceptions and evaluations (García-Marzá, 2004).

On the other hand, responding is a communicative action. Responding seeks understanding and agreement from the organizations to which the response is directed, which in this case it is directed to the interest groups that compose the organization. Habermas describes the difference between communicative action and strategic action and the consequent prioritization of communicative action (Habermas, 1987; García-Marzá, 1992). The strategy, the search for influence over or effect on the receiver, such as, for example, the generation of trust, is based on the expectation that a series of assumptions or conditions are being met. Habermas calls these conditions validity claims, which refer to

- their truthfulness or sincerity, i.e., the intention of the communication;

- their truth, i.e., their reference to reality;

- their justice, i.e., the consideration of another as a person who has the same rights and abilities as the transmitter (Figure 1).

These validity claims, which we accept when we trust the information that is offered, help us to remember that informing is not the same as communicating. These validity claims also help us to remember that we must make all information production and transmission processes subject to these conditions, which underlie all communicative pro- cesses and define responsible communication. This requirement applies not only to the public. Rather, equal consideration should be accorded to all of the involved actors who are understood to be valid speakers (Habermas, 1987; Cortina, 2007). Reconstructing this essentially communicative nature of social responsibility allows us to identify, define, and manage the ethical basis of trust in the same communication.

Developing an ethics of communication consists of explaining, justifying, and managing these assumptions or validity claims in each communicative practice and in the organizational contexts in which communication is conducted so that an ethical framework can be established for our professional work. The experience and continuity of relationships may inform us regarding compliance or non-compliance with these claims. However, we can also establish an organizational design that generates from the outset trust in the intention of what is said, its truthfulness or the justness of the established relationships. This is the basic function of an ethical infrastructure that integrates the different elements of current ethics and compliance programs.

It is not only a question of professional ethics, which are essential, but it is also a question of thinking about our organizations in such a way that responsible communication and the responsibility of communication are two sides of the same coin. If corporate social responsibility is the way in which each organization answers for its ethical commitment, efforts and results, then communication itself is an essential, not subsequent and discretionary, part of this process. This idea should be embodied in the same institutional structure in which design reflects what Kant called a principle of publicity that bridges theory and practice, as well as ideas and their implementation. A principle of responsibility indicates that trust is directly proportional to the ability of organizations to make public their decisions and actions and to acquire the consent and agreement of all the involved parties (García-Marzá, 2012).

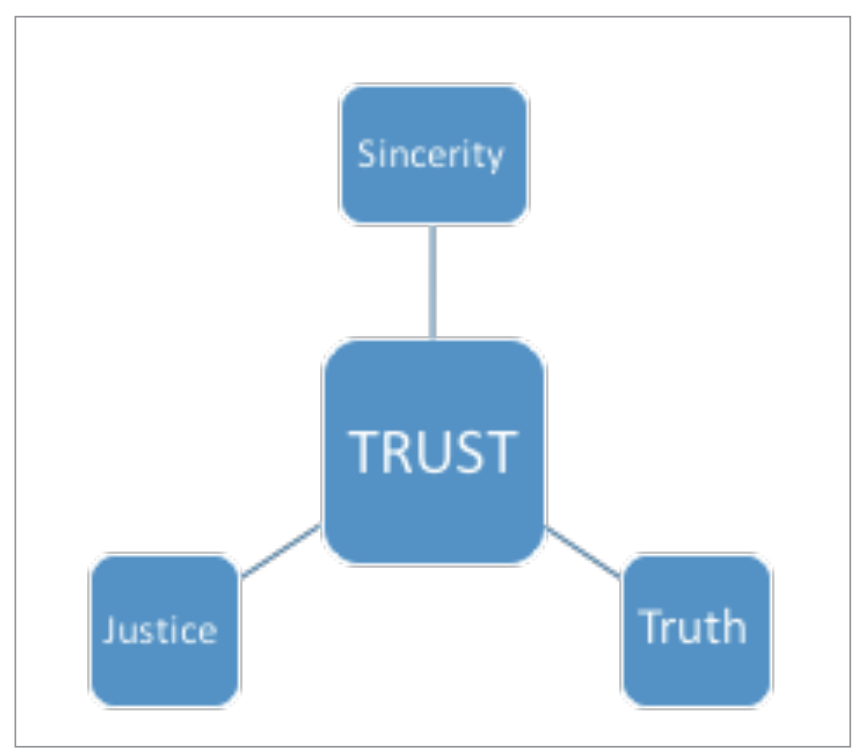

Figure 1. Validity claims 
According to this principle, transparency, access to information, and the dissemination of the impacts that are generated by the organization should always be accompanied by a discursive justification that requires the participation and when possible, the agreement of all interested groups. In reference to this need for transparency and participation, we propose a rethinking of the meaning of ethical codes and ethical auditing.

\section{Ethics and compliance programs should} integrate four elements to build an ethical infrastructure: an ethical code of conduct; social responsibility reports; an ethics committee; and an ethics hotline

\section{Towards a new generation of ethical codes}

It is evident that trust has a psychological component. Trust is a belief in the future behavior of a person or organization. However, trust also has a rational basis or a group of intersubjective reasons that support this belief and that motivate our perception and evaluation as clients, workers, students, patients, etc. The most important among these reasons is the knowledge that we are dealing with organizations that are committed to behaving responsibly and fulfilling this commitment. If trusting means having a reason to expect something, this information can motivate our decisions and subsequent actions (García-Marzá, 2004).

To take this step, we need more than a declaration of good intentions from a professional and, in our case, an organization. According to this principle of responsibility, all management of the information that intends to demonstrate the fulfillment of social responsibility should, in each particular situation, first make public the efforts that are made by the organization. This exposure is not only a matter of a sincere willingness. Rather, this willingness acquires the rank of a public commitment in the double sense of transparency and participation. The theories of institutional design utilize this idea and attribute the ability to produce trust to this "discursive justification potential" (Goodin, 2003).

At first, design appears to be a pretentious and risky term. However, this first impression of the term disappears when we realize that its etymological root designare indicates the designation of the principles that are used to determine which type of social agreements, or systems of rules, we prefer to maintain and reproduce and which social agreements we prefer to change. Although design and redesign are intentional activities, they should always be understood as contributions to the public discourse regarding which ethical infrastructure is the most apt for enabling our organizations and their internal and external communications and for generating trust. That is, design or redesign should be understood as a contribution to the public discourse on how the credibility and reputation of an organization can be sustained and developed.

Therefore, the good will of a professional is insufficient to address this public justification. Instead, we should depend on organizational processes and structures that allow for and strengthen responsible communication; not only information management, but also communication management, given that the generation of trust demands both opening and accessing information, as well as the possibility of participation and an agreement between the involved parties in an organization's activity. In order to anchor the ethical basis of communication, we need both:

- the transparency of information;

- the participation of different interest groups.

The mechanisms that have been traditionally used to determine the ethical commitment of an organization, for example its commitment to social responsibility, have been organizational codes of ethics and more recently, social responsibility reports or sustainability reports. However, as we show here, we must integrate these mechanisms into a broader organizational design that includes not only transparency, but also participation. Figure 2 shows the key parts of this proposal for a program of ethics and compliance in organizations.

\section{Code of ethics and conduct}

The first step in a generation of trust is the production and publication of ethical codes of conduct. This step includes using formal documents where we find an explicit declaration of the values that should orient the conduct of employees and managers, promoting good practices and indicators about the organization's nature and personality (Schwartz, 2004; Lozano-Aguilar, 2007). The function of this first step is twofold:

- from an internal point of view it formalizes the values and decision-making criteria that define the organizational culture itself, as well as the conduct that is expected of employees; and,

- from an external point of view, the function is to manage an organization's reputation.

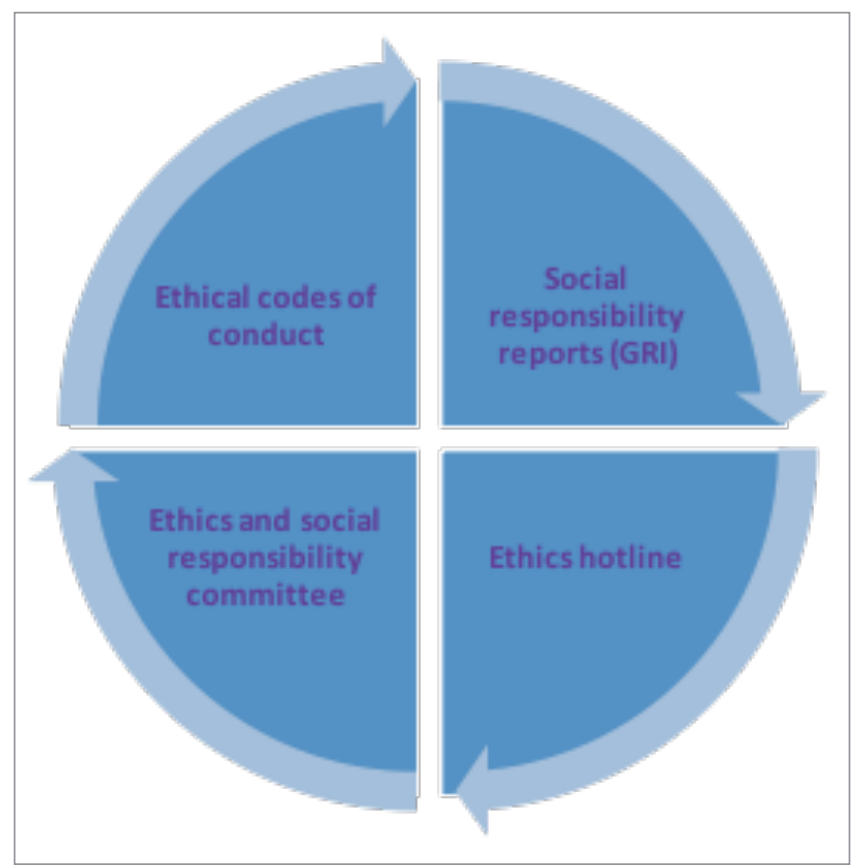

Figure 2. Elements of an ethical infrastructure 
Thus, this step presents us with the values that define an organization's nature or ethics and also with the commitments that the organization is willing to make to create this common will and the types of conduct that it requires (García-Marzá, 2004).

The importance of these corporate codes grows with the global nature of many of the problems that organizations must confront, whether they are corporations, administrations, or civic and solidarity organizations. Because corporations are always limited by state borders, national laws can do little to respond to these global and multicultural challenges. The same inability is the case with tradition itself, which varies according to each particular culture and religion. Ethical codes, however, present some values, commitments, and behaviors that are specific to an organization wherever it may operate and thus reveal an organization's particular nature and way of being and doing. Ethical codes reveal an ethical commitment that should accord with the moral values that are expressed in international guidelines and agreements, such as the Global pact or the Sustainable development goals (Stohl; Stohl; Popova, 2009).

However, the lack of precision in the presented values and the frequent lack of compliance with commitments and regulated conduct has spread doubt and mistrust of these ethical codes. The lack of participation of employees and other groups in the production of these self-regulation mechanisms has decreased their efficacy, and frequent fraudulent practices have diminished their credibility in the public eye (Hernández-Zubizarreta; Ramiro-Pérez, 2009). For many organizations, ethical codes are the beginning and end of corporate social responsibility communication, as if declaring good will is sufficient enough. These organizations forget that ethical codes are merely the first step in trust building, not the last or only step.

\section{Corporate social responsibility report}

Social responsibility reports and sustainability reports support ethical codes and function as standardized procedures. These reports follow, for example, the Global Reporting Initiative guidelines to present the generated economic, social, and ecological results. These reports provide information on the impacts that are generated by an organization. Transparency may be justified by these reports that provide information regarding management policies and strategies and also results in the form of indicators. However, these reports do not create trust in ethics and compliance programs, and they do not generate trust overall.

Again, we find an explanation in the disconnect between communication and participation. Although organizations may have found a common way to inform about the fulfill- ment of the principles that have been expressed in an ethical code, with the required materiality reports, this information is insufficient to account for the lack of participation of interest groups, especially the participation of external interest groups. The production of these reports by communications management, CSR, or even worse, by specialized consultants who then themselves verify the offered information, does not achieve credibility. As we will see, another question is whether these can be considered arguments in an ethics and social responsibility committee's process of arriving at agreements.

The proposal that is defended here does not consist of renouncing these two steps that are necessary to generate trust in the information that is offered. Rather, this proposal integrates the need for transparency with the need for participation in such a way that these two instruments of information regarding social responsibility are supported by the participation of all the interest groups that are involved in and affected by organizational activity. To achieve this objective, the compliance mechanisms should be included in the ethical code itself, as opposed to being separate from it (Figure 3). In this respect, we indicate innovation and, more importantly, a new generation of ethical codes because these codes incorporate participation, not only in the definition of the commitments, but also in the monitoring and control of their fulfillment.

This new generation of ethical codes goes beyond the current ethics and compliance programs that are always limited to the legal field and that are only concerned with criminal risks (Peterson, 2013; Weber; Wasieleski, 2013). The current ethics programs do not consider that the moral risks or the possibility that an organization does not behave according to what is expected of it can have even worse repercussions. Credibility and trust are at stake. Thus, the two remaining parts attempt to reduce the distance between the communication of social responsibility and participation.

\section{Ethics committee and CSR}

An ethics and corporate social responsibility committee is considered a space for participation and dialogue among the different interest groups in an organization. This com-

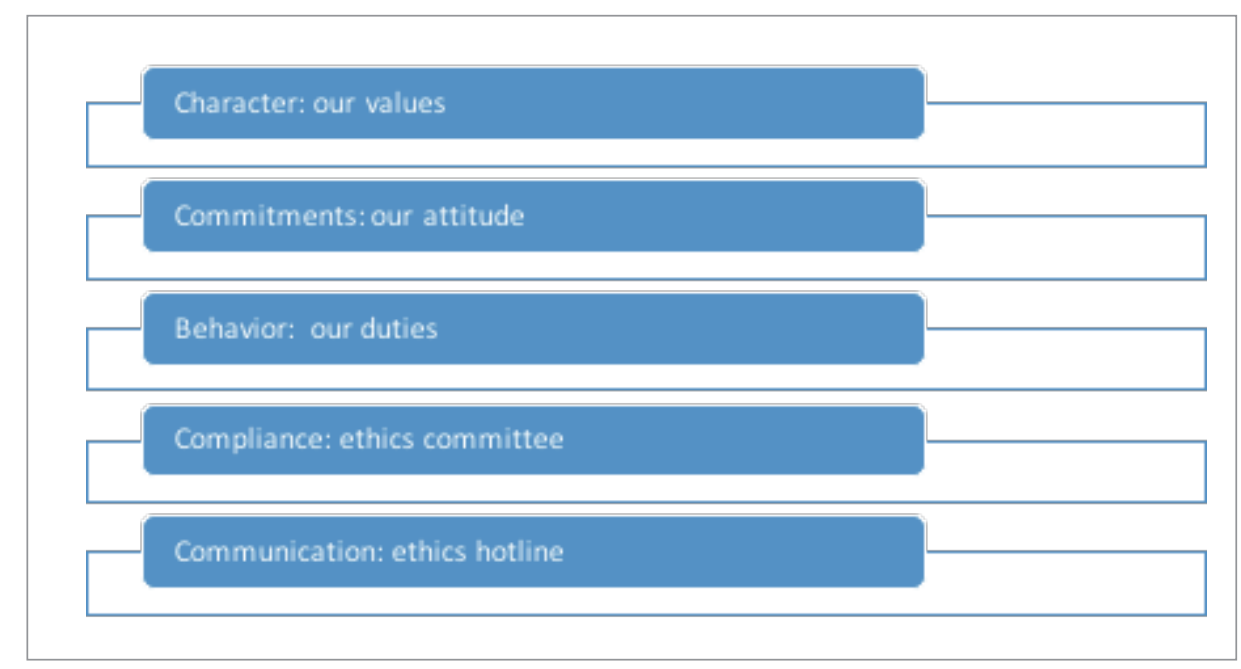

Figure 3. Ethical code of conduct structure 
mittee is in charge of the monitoring and control of the ethics and compliance program, and it drives the ethics and social responsibility of an organization. This committee has the following three functions:

- advising on the subjects regarding the interpretation and application of an ethical code;

- resolving notifications concerning suggestions, alerts, and complaints that are made through an ethics hotline;

- promoting the informing of employees and managers on the ethics and compliance program and their inclusion in its formation.

An ethics and social responsibility committee is always conscious of the fact that the idea is to aid in the management of and compliance with the values and norms that are expressed in the ethical code of conduct. Trust in the committee will depend on the trust that its members can generate (García-Marzá, 2004).

For example, professionals in the field of communication of corporate social responsibility should produce reports and the relevant corporate information. Furthermore, these reports should always pass through the filter of an ethics committee, which should also include external interest groups. Of course, membership in an administration council or in any other organization with particular interests invalidates ethics committee membership. Table 1 shows an ethics committee's basic rules of operation.

The new generation of codes of ethics must incorporate participation and communication not only in the definition of the commitments but also in the monitoring and control of their compliance

However, the participation that is sought cannot be limited to a small committee that, although it provides a presence and voice to internal and external interest groups, does not substitute for the voice of all. We should establish communication channels that allow for the participation of all that want to participate and that always center on the fulfillment of the adopted ethical commitments. Communication should not be limited to complaints concerning bad practices. An ethical culture should include the involvement of employees in alerting, preventing, and detecting situations and conflicts of interest that can yield to a lack of compliance, which damages a corporation's reputation (Lee; Fargher, 2013; Calvo-Cabezas, 2015). The same damage can occur to external groups, users, clients, suppliers, etc. The goal is to progress to an ethical culture where the prevention and detection of bad practices is a shared responsibility.

\section{Ethics hotline: an alerts and complaints system}

This detection of bad practices is a role that an ethics hotline fulfills, which is understood as a communication channel to express suggestions, alerts, and complaints. In any format (i.e., postal mail, electronic mail, web, etc.), it is a matter of communicating a lack of compliance with an ethical code and suggestions for its improvement. Of course, communication should always be confidential, but never anonymous
Table 1. Ethical principles for an ethics and corporate responsibility committee

\begin{tabular}{|l|l|}
\hline Independence & $\begin{array}{l}\text { Actions and recommendations are always made } \\
\text { within the ethical framework that is defined in } \\
\text { the ethical code of conduct and by ensuring, at } \\
\text { all times, that there is justice and impartiality in } \\
\text { decision making }\end{array}$ \\
\hline Transparency & $\begin{array}{l}\text { Access to information and to the committee's } \\
\text { decisions is guaranteed for all authorized per- } \\
\text { sons, and confidentiality is safeguarded }\end{array}$ \\
\hline Consensus & $\begin{array}{l}\text { All decisions and recommendations are arrived } \\
\text { at by the unanimous agreement of committee } \\
\text { members, and deliberation is always pursued in } \\
\text { the committee's operations }\end{array}$ \\
\hline
\end{tabular}

(Johansson; Carey, 2016). Protocols that are necessary to ensure confidentiality and avoid all possible reprisals should be established. Thus, suggestions, alerts, and complaints should be directed at the ethics committee, not only at the person who is in charge of ethics and compliance.

Ultimately, we are addressing different progressive steps to generate trust in the communication of organizations' social responsibility and to provide arguments that we are dealing with the ethical management of communication, not simply strategic communication. These steps are not independent from one another. Rather, these steps compose a system in the way that they refer to one another when we consider managing trust because it is the final product of this interrelation. Simultaneously, the existence and operation of this ethical infrastructure must be externally verified. This is the role of ethical auditing.

\section{Ethical auditing as an instrument to manage corporate communication}

Presently, compliance programs are far from sustaining themselves with the ethical management of social responsibility communication. These programs are more concerned with criminal responsibility; the ambiguity of the programs makes them inapplicable to public or private corporations, or they are concerned with avoiding some criminal risks, despite the demonstrated ineffectiveness of the mechanisms that are enabled for compliance (Beltrán-Orenes; Martínez-Pastor, 2016). However, the ethics and compliance program that we present is supported by responsible communication as a basic instrument to generate trust, and the strength of its compliance lies in its construction of a common good will. This program is not concerned with punishing offenders but rather creating a culture where transparency and participation discourage bad practices and acknowledge and strengthen good practices.

In this respect, we have discussed the management of moral risks and of the mistrust that leads to not knowing whether the organization will or will not fulfill the expectations for it. To this end, we introduced in the first point the principle of responsibility, as a requirement of responsible communication that can inform the fulfilment of the validity claims that uphold this trust. This principle also provides information regarding the rule that Davis formulated decades ago in the Iron law of social responsibility: 
"Society grants corporations legitimacy and power. In the long run, those who do not use this power in a way that society considers responsible tend to lose it" (Davis, 1975).

However, in complex and global contexts, it is difficult to delimit the boundaries of the concept of "society". For ethics and compliance programs, society becomes an interest group that represents general interests, such as respect for and the promotion of human rights or protecting and caring for the environment. However, the reliability of the information that is offered cannot be supported only by these spaces of participation that ethics committees provide. Although the committees incorporate external interest groups, as is the case with society, they continue to belong to the organizational structure itself. Accordingly, the representation of society cannot be limited to a seat on an ethics committee. Thus, social responsibility communication identifies the public opinion sphere as the voice of civil society and the means by which the general interests that are shared by all groups are expressed (CaseroRipollés, 2017). Ethical auditing exists as an opportunity and as a convenience in the process of producing a system for public information regarding the fulfillment of an organization's ethical commitment.

Although we can trace the origins of ethical auditing back to social balance, in the presentation and verification of the social impacts of corporate activity, ethical auditing should not be confused with social auditing.

Social auditing is directed at the systematic and documented evaluation of the results that are presented by an organization in its social responsibility reports or in any other corporate document where it expresses its commitments. This evaluation is conducted by an officially accredited entity or organization.

The goal is to progress to an ethical culture where the prevention and detection of bad practices is a shared responsibility

Ethical auditing, in contrast, is directed at the verification and evaluation of an ethics and compliance program's operation more than it is directed at impacts. Ethical auditing demonstrates that an organization "is serious" and that social responsibility is not a mere strategy but rather forms part of an organization's ethics, that is, its nature or way of being and doing. Ultimately, ethical auditing is concerned with verifying and assessing an organization's ethical commitment on which both the transparency and the participation of an organization's ethics and compliance system is based.

The objective of ethical auditing is to gather and evaluate the levels of commitment and acceptance on the part of interest groups that characterizes ethical management. Ethical auditing has a double function:

- On the one hand, it serves as a calling card that identifies an organizations' nature and ethics to other organizations, whether these organizations are in the market, civil society, or administration.
- On the other hand, ethical auditing provides information to an ethics and social responsibility committee to measure the efforts that have been made and to improve good practices. Ethical auditing is a methodical and systematic record that indicates where an organization is and how it can progress. Ultimately, ethical auditing is a basic resource for dialogue among all of the involved actors (GarcíaMarzá, 2005)

For ethical auditing, we need a common language or a common measure that allows for both this public presentation of and dialogue within the ethics committee. We must turn this ethical commitment into a series of verifiable indicators in the sense of intersubjectively contractables that can become intersubjectively valid reasons. This independence, this nature, is external to the organization and should aid in the building of trust. Thus, it is better when auditing organizations are further from the market and from supply and demand (Treviño et al., 1999).

Ethical auditing demonstrates that an organization is "serious" and that social responsibility is not merely strategy, but rather forms part of an organization's ethics, that is, its nature or way of being and doing

The proposed methodology to conduct these audits is derived from Habermas's Theory of Communicative Action and from the discursive ethics that are applied to organizations, which purport that their legitimacy, and therefore their credibility, depends on the possible agreement among all of the involved interest groups. For this reason, we should use two types of indicators and integrate two types of data:

- On the one hand, there is the data that pertains to the perspective of the spectator who Habermas calls the "third person". This perspective requires the use of objective data that is used to measure the states, facts, or conditions that can be observed and contrasted. These data can be quantified in terms of monetary costs, the number of interventions, frequencies, etc.

- On the other hand, we also need to know the perception of the involved actors themselves. This is subjective data that is used to measure the perception of the actors who are involved in the organization's reality. This measurement must be complemented by a map of the interest groups, their interests and possible conflicts (GonzálezEsteban, 2007). These data can be gathered through interviews, surveys, polls, discussion groups, etc.

When evaluating compliance, an audit should use two perspectives: (1) the perspective of the third person or spectator, and (2) the perspective of the first person or participant. Both positions are necessary to avoid biased visions and to enable their integration. Our proposal synthesizes this information in three steps so that it is relatively simple to provide an assessment regarding whether an organization acts from conviction or from convenience (Figure 4). These steps are described as follows. 
1) The adequacy of the values and commitments are presented in the ethical code regarding the coherency and consistency of the following two basic levels:

- the level of the ethical code values regarding different guidelines and international agreements as an expression of what society expects of the organization according to the good that it purports to contribute, such as health, education, the creation of shared value, etc.; and

- the level of the ethical code values regarding the commitments that are acquired for their fulfillment and the conduct and organizational practices that are designed for their development, ultimately among the different elements of the ethics and compliance program.

2) The verification of the objective and provable information is conducted regarding the activities of the different elements of the ethics and compliance program. This verification includes contrastable data; for example, the budget that is assigned to the ethics committee, number of meetings, ethical training programs conducted, number of complaints and responses, resolved conflicts, etc.

3) The perception of the different interest groups demonstrates their degree of acceptance of the corporation's ethical conduct and the satisfaction of the legitimate interests that are at stake, as well as the interest groups' appreciation of the efficiency of the ethics and compliance program and the frequency and intensity of bad practices.

\section{Conclusion}

A lack of compliance with commitments and regulated conduct coupled with their strategic and instrumental use, have caused a crisis in the management and communication of social responsibility in organizations. This crisis has spread doubt and mistrust about these commitments and regulated conduct, which need to be updated. For this purpose, an ethics of communication that is based on the theory of communicative action and on the discourse ethics can be formulated as the basis on which to design the different mechanisms of transparency and participation. In this article, a model for the integration of the following four elements has been proposed:

- an ethical code of conduct;

- social responsibility reports;

- an ethics committee;

- an ethics hotline.

This model's validity and verification depends on an ethical audit that would need to be external to the organization. The ethical audit is justified by the demand for transparency and participation that underlies the possible agreement between all of the interest groups (Sorsa; 2008; Orozco-Toro; Ferré-Pavía, 2013).

Whether as a document to facilitate dialogue and the formulation of agreements in the ethics committee or as the organization's calling card in a complex and global context, ethical auditing has a fundamental importance for social responsibility communication. Thus, ethical auditing should be seen as an external complement to an ethical code and to the elements of the ethics and compliance system that it contains. In this way, we finish our proposal for the creation of an ethical infrastructure that ensures credibility and

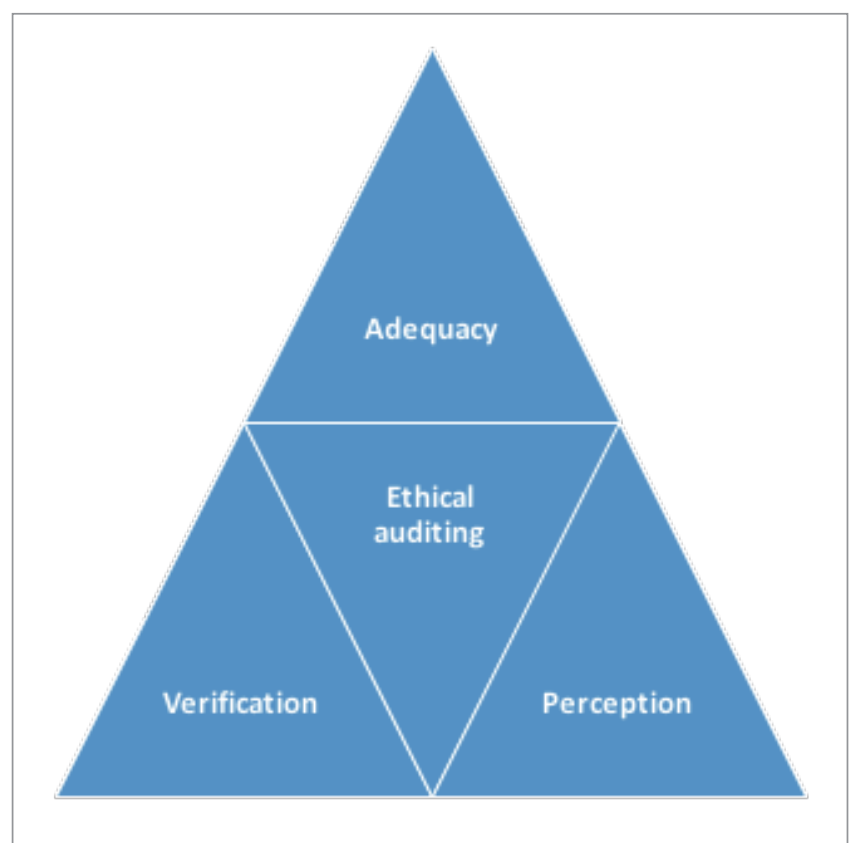

Figure 4. Three steps for ethical auditing

trust in social responsibility communication. The design of this infrastructure may appear complex, but its production and implementation are already part of an organizational learning process that anchors the responsibility of corporate communication in the ethical basis of trust.

\section{Funding}

This study is part of the research project FFI2016-76753-C2$2-\mathrm{P}$, which is funded by the Spanish government's Ministry of Economy and Competitiveness (Ministerio de Economía y Competitividad). The proposal that is presented here is currently being applied to the plans for the University of Social Responsibility at the Jaume I University (Universitat Jaume l) (http://www.uji.es).

\section{Bibliography}

Aceituno-Aceituno, Pedro; Cea-Moure, Ramiro; CasadoSánchez, José-Luis; Ruiz-de-Azcárate-Varela, Carmen (2013). "La comunicación como factor clave en la implantación de la responsabilidad social corporativa: el caso de Crédit Agricole España". El profesional de la información, v. 22, n. 4, pp. 326-332.

https://doi.org/10.3145/epi.2013.jul.08

Beltrán-Orenes, Pilar; Martínez-Pastor, Esther (2016). “Grado de cumplimiento de las leyes de transparencia, acceso y buen gobierno y de reutilización de los datos de contratación de la administración central española". El profesional de la información, v. 25, n. 4, pp. 557-566.

https://doi.org/10.3145/epi.2016.jul.05

Calvo-Cabezas, Patrici (2015). "Responsabilidad social ético-discursiva: whistleblowing como mecanismo de participación de la sociedad civil”. Neumann business review, v. 1, n. 2, pp. 1-22.

http://www.journaltop.com/index.php/NBR/article/view/10

Casero-Ripollés, Andreu (2017). “Producing political content 
for web 2.0: Empowering citizens and vulnerable populations". El profesional de la información, v. 26, n. 1, pp. 13-19. https://doi.org/10.3145/epi.2017.ene.02

Cortina, Adela (2007). Ética de la razón cordial. Oviedo: Nobel. ISBN: 9788484591795

Cortina, Adela; García-Marzá, Domingo (2003). Razón pública y éticas aplicadas. Los caminos de la razón práctica en una sociedad pluralista. Madrid: Tecnos. ISBN: 8430939555

Davis, Keith (1975). "Five propositions for social responsibility". Business horizons, v. 18, n. 3, pp. 19-24.

García-Marzá, Domingo (1992). Ética de la justicia. Jürgen Habermas y la ética del discurso. Madrid: Tecnos. ISBN: 978 8430921898

García-Marzá, Domingo (2004). Ética empresarial: del diálogo a la confianza. Madrid: Trotta. ISBN: 9788498792263

Garcia-Marzá Domingo (2005). "Trust and dialogue: Theoretical approaches to ethics auditing". Journal of business ethics, v. 57, pp. 209-219.

https://goo.gl/Bu24Zy

https://doi.org/10.1007/s10551-004-8202-7

García-Marzá, Domingo (2012). “Kant's principle of publicity". Kant-studien. Philosophische zeitschrift der Kant-gesellsschaft, v. 103, n. 1, pp. 96-113.

https://doi.org/10.1515/kant-2012-0005

García-Marzá, Domingo (2014). “La RSC en perspectiva ética". Mediterráneo económico, v. 26, pp. 239-254. ISBN: 978 8495531667

http://www.publicacionescajamar.es/pdf/publicacionesperiodicas/mediterraneo-economico/26/26-698.pdf

González-Esteban, Elsa (2007). "La teoría de los "stakeholders": un puente para el desarrollo práctico de la ética empresarial y de la responsabilidad social corporativa". Veritas: revista de filosofía y teología, v. 2, n. 17, pp. 205-224. http://www.redalyc.org/pdf/2911/291122924002.pdf

Goodin, Robert E. (ed.) (2003). Teoría del diseño institucional. Barcelona: Gedisa. ISBN: 9788474328523

Habermas, Jürgen (1987). Teoría de la acción comunicativa. Madrid: Taurus. ISBN: 9788430603398

Habermas, Jürgen (1998). Facticidad y validez. Madrid: Trotta. ISBN: 8481641510

Hernández-Zubizarreta, Juan; Ramiro-Pérez, Pedro (2009). El negocio de la responsabilidad social. Crítica de la responsabilidad social corporativa de las empresas transnacionales. Barcelona: Icaria. ISBN: 9788498881042

Johansson, Elka; Carey, Peter (2016). "Detecting fraud: The role of the anonymous reporting channel". Journal of business ethics, v. 139, pp. 391-409.

https://goo.gl/8VxclU

https://doi.org/10.1007/s10551-015-2673-6

Klein, Naomi (2011). No logo: el poder de las marcas. Barcelona: Planeta. ISBN: 9788408104322

Laufer, William S. (2003). "Social accountability and corporate greenwashing". Journal of business ethics, v. 43, n. 3, pp. 253-261.

https://goo.gl/3ijflQ

https://doi.org/10.1023/A:1022962719299

Lee, Gladys; Fargher, Neil (2013). “Companies' use of whistle-blowing to detect fraud: An examination of corporate whistle-blowing policies". Journal of business ethics, v. 114, pp. 83-295.

https://doi.org/10.1007/s10551-012-1348-9

López-Aranguren, José-Luis (1979). Ética. Madrid: Alianza. ISBN: 8420680192

Lozano-Aguilar, José-Félix (2007). "Códigos éticos y auditorías éticas". Veritas, v. 2, n. 17, pp. 225-251.

https://dialnet.unirioja.es/descarga/articulo/2471548.pdf

Moreno-Izquierdo, José-Antonio (2014). “RSC. Para superar la retórica". Economistas sin fronteras, n. 14, pp. 4-11.

https://goo.gl/mbWGXh

Orozco-Toro, Jaime-Alberto; Ferré-Pavía, Carme (2013). “La comunicación estratégica de la responsabilidad social corporativa". Razón y palabra, n. 83.

http://www.razonypalabra.org.mx/N/N83/V83/20_OrozcoFerre V83.pdf

Peterson, Evan A. (2013). "Compliance and ethics programs: Competitive advantage through the law". Journal of management \& governance, v. 17, n. 4, pp. 1027-1045. https://doi.org/10.1007/s10997-012-9212-y

Rademacher, Lars; Köhler, Andreas (2012). "More than a legal issue? Compliance communication as a tool for reputation management". Sinergie. Italian journal of management, v. 88, pp. 35-52.

http://sinergiejournal.eu/index.php/sinergie/article/view/ S88.2012.04

Schwartz, Mark S. (2004). "Effective corporate codes of ethics: Perceptions of code users". Journal of business ethics, v. 55, n. 4, pp. 321-341.

https://doi.org/10.1007/s10551-004-2169-2

Sorsa, Ville-Pekka (2008). "How to explain socially responsible corporate actions institutionally: Theoretical and methodological critique". Electronic journal of business ethics and organization studies, v. 13, n. 1.

https://jyx.jyu.fi/dspace/handle/123456789/25416

Stohl, Cynthia; Stohl, Michael; Popova, Lucy (2009). "A new generation of corporate codes of ethics". Journal of business ethics, v. 90, n. 4, pp. 607-622.

https://goo.gl/07hV7L

https://doi.org/10.1007/s10551-009-0064-6

Treviño, Linda K.; Weaber, Gary R.; Gibson, David G.; Toffler, Barbara L. (1999). "Managing ethics and legal compliance: What works and what hurts". California management review, v. 41, n. 2, pp. 131-151.

https://doi.org/10.2307/41165990

Weber, James; Wasieleski, David M. (2013). “Corporate ethics and compliance programs: A report, analysis and critique". Journal of business ethics, v. 112, n. 4, pp. 609-626. https://goo.gl/uy3ffu https://doi.org/10.1007/s10551-012-1561-6 